NBER WORKING PAPER SERIES

\title{
THE EFFECT OF MARGINAL TAX RATES ON TAXABLE INCOME: A PANEL STUDY OF THE 1986 TAX REFORM ACT
}

\author{
Martin Feldstein
}

Working Paper No. 4496

\author{
NATIONAL BUREAU OF ECONOMIC RESEARCH \\ 1050 Massachusetts Avenue \\ Cambridge, MA 02138 \\ October, 1993
}

This paper extends a previously circulated unpublished paper ("A Preliminary Report on the Effects of Marginal Tax Rates on Taxable Income," May 1993). I am grateful to John Navrutil and Dan Feenberg for their help with the calculations and for discussions about this subject. I have also benefitted from comments on the previous draft by Michael Boskin, David Bradford, Kate Feldstein, John Gruber, Jim Hines, Jeff Liebman, Lamy Lindsey, Jim Poterba, Jonatlian Skinner and other colleagues at the NBER and Harvard. This paper is part of the NBER study of the Effects of Taxes on Economic Activity and the NBER research program in Public Economics. Any opinions expressed are those of the author and not those of the National Bureau of Economic Research. 


\title{
THE EFFECT OF MARGINAL TAX RATES \\ ON TAXABLE INCOME: A PANEL STUDY \\ OF THE 1986 TAX REFORM ACT
}

\begin{abstract}
This paper reports new estimates of the sensitivity of taxable income to changes in tax rates based on a comparison of the tax returns of the same individual taxpayers before and after the 1986 tax reform. This comparison is done by using a panel of more than 4000 individual tax returns created by the Treasury that matches tax returns for the same taxpayers in different years.

The analysis emphasizes that the response of taxable income is much more general than the response of traditional measures of labor supply and is likely to be much more sensitive to tax rates.

The evidence shows a substantial response of taxable income to changes in marginal tax rates. The differences-of-differences calculations imply an elasticity of taxable income with respect to the marginal net-of-tax rate that is at least one and could be substantially higher.

There is a brief discussion and simulation analysis of the implications of these estimates for the likely impact of the 1993 tax rate increases on tax revenues. Even the lowest estimated elasticity implies that the tax rate changes enacted in 1993 will lead to little additional personal income tax revenue.
\end{abstract}

Marin Feldstein

NBER

1050 Massachusetts Avenue

Cambridge, MA 02138

and Harvard University 
The Effect of Marginal Tax Rates on Taxable Income:

A Panel Data Study of the 1986 Tax Reform Act

Martin Feldstein*

Changes in marginal tax rates induce taxpayers to alter their behavior in ways that affect taxable income and therefore tax revenue. The magnitude of this response is of critical importance in the formulation of appropriate tax and budget policies. This paper reports new estimates of the sensitivity of taxable income to changes in tax rates based on a comparison of the tax returns of the same individual taxpayers before and after the 1986 tax reform. This comparison is done by using a panel of more than 4000 individual tax returns created by the Treasury that matches tax returns for the same taxpayers in different years. Although the Treasury panel data have been used in other studies, this is the first time that panel data have been used to estimate the sensitivity of taxable income to marginal tax rates.

The Tax Reform Act of 1986 is a particularly useful natural experiment for studying the responsiveness of taxpayers to changes - - - -

- Professor of Economics, Harvard University and President of the National Bureau of Economic Research. This paper extends a previously circulated unpublished paper ("A Preliminary Report on the Effects of Marginal Tax Rates on Taxable Income," May 1993). I am grateful to John Navratil and Dan Feenberg for their help with the calculations and for discussions about this subject. I have also benefitted from comments on the previous draft by Michael Boskin, David Bradford, Kate Feldstein, John Gruber, Jim Hines, Jeff Liebman, Larry Lindsey, Jim Poterba, Jonathan Skinner and other colleagues at the NBER and Harvard. This paper is part of the NBER study of the Effects of Taxes on Economic Activity.

(tra3.930) 
in marginal tax rates. The 1986 legislation reduced tax rates

sharply for high income individuals. The marginal tax rates of the highest income individuals fell from 50 percent to 28 percent, raising their marginal net-of-tax income per dollar of pretax income by 44 percent (from 50 cents to 72 cents).

The analysis presented in this paper shows that there is a very substantial response of taxable income to changes in marginal tax rates. The estimated sensitivity of taxable income to variations in marginal income tax rates implies that a change in income tax rates has substantially less impact on tax revenue than would be true if there were no behavioral response to marginal tax rates. This sensitivity of taxable income also implies that high marginal tax rates create significant deadweight losses by inducing taxpayers to act differently than they otherwise would. ${ }^{1}$ Both implications are relevant to the design of appropriate tax policies and to choices about the desirable level of government spending.

Section 1 of this paper reviews some of the previous literature on the effects of income tax rates and discusses the importance of understanding how changes in tax rates induce taxpayers to alter their taxable income as a whole and not just their labor supply. The second section describes the data used in the present study and considers the advantages and disadvantages of

1 The behavioral changes induced by higher marginal tax rates include not only changes in labor supply but also a wide range of other changes discussed in section 1 of this paper. All such changes in behavior involve deadweight losses to the individual because they alter the way that potential income is spent (e.g.. on leisure, on fringe benefits, on tax deductible consumption like charitable gifts, etc.) 
these panel data relative to the data used in previous studies. Section 3 reviews the relevant features of the 1986 tax reform and discusses how the data will be analyzed to separate the effects of changes in marginal tax rates from the effects of the 1986 changes in tax rules.

The basic analysis is presented in section 4 and the implied elasticities are presented and discussed in section 5. A separate analysis of the response of wage and salary income is reported in section 6 . Section 7 then applies the estimated elasticities to assess the likely effects of the increased marginal tax rates enacted in 1993. There is a brief concluding section.

\section{The Effects of Tax Rates on Taxable Income}

A change in individuals' marginal income tax rates can induce them to alter their taxable income in a wide variety of ways including changes in labor supply, changes in the form in which employee compensation is taken, changes in portfolio investments, changes in itemized deductions and in other expenditures that reduce taxable income, and changes in taxpayer compliance.: Understanding the effect of tax rates on revenue requires assessing the response of overall taxable income and not just the effect on labor supply.

Economists and other analysts who are skeptical about the

\footnotetext{
${ }^{2}$ The sum of an individual's income from all sources minus certain expenses and other "adjustments" is called Adjusted Gross Income (AGI). Subtracting "itemized deductions" from AGI results in "Taxable Income."
} 
adverse effect of higher marginal tax rates on taxable income generally point to the literature on the effects of taxes on labor supply. Much of this literature shows that net wage rates have little effect on the labor force participation rate of adult males and on the average number of working hours of those in the labor force (e.g., Pencavel (1986) and Triest (1990).) This evidence has been interpreted as indicating that high marginal rates have little effect on taxable income.

Although the current study deals with taxable income more generally, it is worth considering three reasons why this evidence substantially underestimates the effect of tax rates on labor supply. First, most of the studies disregard the nonlinearity of the income-leisure opportunity locus that results from the progressivity of the tax schedule and the existence of other household income (investment income and second earner income). Hausman (1991) showed that ignoring this problem causes a substantial underestimate of the effect of increases in marginal tax rates. Although critics of Hausman's estimates (Heckman, 1993; Macurdy et. al., 1990 and Triest, 1990) argue that his results reflect the particular functional form that he adopted, the analysis in the current paper indicates that high elasticities of taxable income with respect to the after-tax rate are obtained by a method that imposes no restrictions on functional form.

second, many studies have shown that female labor force participation and hours are much more sensitive to net wages and to taxes than male labor supply (e.g., Rosen, 1976; Hausman, 1991; and 
Eissa, 1993). Although Mroz (1987) in his review of the literature reports low elasticities of hours supplied among working women, he concludes that the participation decision is quite responsive. Since females now constitute more than 45 percent of total civilian employment, looking exclusively at male employment behavior significantly understates the overall responsiveness of the labor force.

Third, the studies focus on labor force participation and hours because those are the aspects of labor supply that are easily measured. In actual practice, individuals can vary their labor supply in the short run by changing how hard they work and in the long run by where they locate and the types of jobs that they accept. These dimensions of labor supply may be particularly important for higher income individuals who have substantial discretion about the intensity with which they work and for whom variations in effort can substantially affect income even if the number of hours is unchanged. By focusing on income rather than hours and participation, this study's revenue elasticities will include the effect of effort which previous labor supply studies of hours and participation have implicitly ignored.

variations in labor supply are not the same as variations in taxable labor income. High marginal tax rates encourage individuals to take their compensation for labor services in forms that are untaxed or subject to lower effective tax rates. Untaxed compensation includes traditional fringe benefits like health insurance as well as such perquisites as corporate cars, in-house 
sports facilities, subsidized corporate dining rooms, child care, first class travel, low interest loans, charitable gift matching programs, etc.. Compensation that is taxed at lower effective tax rates includes pension contributions, nonqualified deferred compensation plans, I ife insurance, and stock options. High income individuals who are self-employed or who are part of a corporation's senior management can have particularly large amounts of discretion about the form of their compensation. More generally, the market will adjust the form of compensation in response to tax changes even for those employees who do not directly shape their own compensation arrangements.

Compensation for labor services is only part of total income. The income from assets that constitutes the rest of compensation provides further opportunities for taxpayers to adjust to changes in tax rates. More specifically, salaries and wages constitute about 75 percent of adjusted gross income for taxpayers as a whole but only about 45 percent of adjusted gross income for taxpayers with AGIs over $\$ 200,000$. For these high income individuals, interest and dividends are 15 percent of AGI and capital gains are an additional 15 percent. Income from rents, unincorporated businesses, and subchapter $S$ corporations make up a substantial part of the rest.

High marginal tax rates encourage individuals to invest their assets in ways that reduce the portion of the return that is included in taxable income. Bonds and high dividend stocks are reduced in favor of untaxed municipal bonds, stocks with low 
dividends and higher potential capital gains, life insurance and annuity products in which funds accumulate tax free, and real estate investments (or other operating businesses) in which cash flow is tax free and rising asset values are taxed as capital gains. ${ }^{3}$ High marginal tax rates on capital gains also cause reductions in the sale of stock and the recognition of taxable capital gains."

These variations in labor supply, in the forms of compensation, and in the structure of portfolio investments can reduce adjusted gross income in response to higher marginal tax rates. In addition, higher levels of deductions for mortgage interest, investment interest, charitable contributions, health insurance, etc. can reduce taxable income further when tax rates rise. ${ }^{5}$

Taken together, existing tax rules provide substantial opportunity for individuals to reduce their taxable incomes by adjusting their income and expenses in response to high marginal

\footnotetext{
${ }^{3}$ Feldstein (1976) shows that marginal tax rates have a substantial effect on the shares of portfolios invested in different types of assets.

'On the effects of tax rates on the realization of taxable capital gains, see Feldstein (1983, chapters 10 through 13), Lindsey (1987a). Auerbach (1988) and Congressional Budget office (1988).

${ }^{5}$ There is substantial evidence on the sensitivity of these deductions to marginal tax rates. See, e.g.. Rosen (1991) and Poterba (1990) on mortgage borrowing. Feldstein and clotfelter (1976) on charitable contributions, and Taylor and Wilensky (1983) and Gruber and Poterba (1993) on health insurance.
} 
tax rates. In addition, high marginal tax rates may induce taxpayers to take more "aggressive" interpretations of tax rules (e.g., claiming questionable deductions) or even to evade taxes by understating income or claiming unjustified deductions.

Previous studies have identified the sensitivity of some of the components of income and expenses to marginal tax rates. The current study examines the extent to which taxable income as a whole responds to changes in marginal tax rates.

\section{A Panel of Individual Income Tax Returns}

The use of an actual panel of individual tax returns permits comparing the taxable incomes and other tax return variables for the same individuals before and after 1986. The data studied here were produced by the Treasury Department as a nonstratified random sample of all tax returns. For each tax return in each year, the available data include essentially all of the information from the form 1040 and some additional information from the other personal income tax forms and schedules that are filed with the form 1040. The current analysis compares the tax returns for 1985 (before the 1986 reductions were enacted or widely anticipated) and for 1988, the most recent year for which such matched data are available.

A panel of tax returns of middle and upper income individuals before and after a major tax change has many advantages over the types of data used in earlier studies of taxpayer responses to marginal tax rates: household survey data, a single cross section of tax return data, and a comparison of two independent cross 
sections of tax return data before and after a tax change.

The use of tax return data rather than of a household survey permits analyzing the response of taxable income as a whole and not just of labor force participation and working hours. These data also reflect the effects of evasion and of aggressive tax strategies that cannot be assessed with hougehold survey data.

The use of a panel in which each individual is observed both before and after the change in tax rates provides a useful way of identifying the effect of the tax change that is not possible with a single cross-section of data. More specifically, the analysis presented in section four permits a comparison of the changes in taxable income reported by taxpayers grouped according to the change in their marginal tax rates. This "difference of differences" form of identification (the differences among these groups in the difference of taxable income between the two years) provides an identification that is not available with a single year's cross section. ${ }^{6}$

Although Lindsey (1987b) did not have panel data, he developed a powerful way to use two separate cross-gection samples of tax returns to approximate the "difference of differences" method of studying the effect of changes in tax rates. To study the effect of the 1981-83 reduction in tax rates on taxable incomes, Lindsey

${ }^{6}$ Single cross sections of tax returns have been useful for studying how marginal rates affect actions like charitable giving and capital gains realizations because individual incomes and taxpayer marginal tax rates can be taken as given. Single cross sections have also been useful for studying the labor supply of married women because differences in their husbands' incomes provides the identifying source of variation in marginal tax rates. 
ranked the individual taxpayers by adjusted gross income in the 1979 Treasury public use sample of individual tax returns and then did the same for the taxpayers in the 1982 sample of individual tax returns. The critical assumption in the Lindsey analysis is that the taxpayers in the successive fractiles corresponded to essentially the same individuals in both years. Conditional on this assumption, he estimated an elasticity of taxable income with respect to the marginal net-of-tax rate (i.e., the net-of-tax income per marginal dollar of pretax income) by relating the changes in the average taxable incomes of individuals in successive fractiles to the changes in their marginal net-of-tax rates. Lindsey's analysis implied a very large elasticity of taxable income to this tax variable. I will return to discuss this estimate in section 4 below.

Eissa (1993) used a related method to study the effect of the 1986 Tax Reform Act on the labor supply of married women. She used Current Population Survey data for 1984 and 1990 to compare the change in labor supply (both the participation rate and average hours per year) of women with high income husbands (for whom the 1986 Act implied a substantial reduction in marginal tax rates) with the change in labor supply of women whose husbands were at the $75 t h$ percentile of income (for whom the 1986 Act implied only a small reduction in marginal tax rates.) Her analysis also found a very substantial elasticity of labor supply with respect to the net-of-tax share implied by the marginal tax rates.

Feenberg and Poterba (1993) used a similar method of comparing 
cross-sections to study how the adjusted gross income of the top one-half of one percent of taxpayers varied over time. Their analysis of the annual tax return independent cross-section samples showed a very substantial jump in the pretax income of this very high income group just after the tax rate reduction enacted in 1986, suggesting that much of the recorded rise in the incomes of high income individuals in the $1980 \mathrm{~s}$ was due to the changes in tax rules rather than to a more fundamental shift in the rewards available to these highest income earners. Feenberg and Poterba did not estimate the changes in taxable income and did not try to analyze how much of the post-1986 rise in the highest incomes was due to changes in taxpayer behavior and how much of it was due simply to different accounting rules.'

Although the Lindsey, Eissa and Feenberg-Poterba comparisons of separate cross-sections provide much useful information, a concern remains about the extent to which the individuals in the same fractile (or husband's income group) in successive crosssections are comparable. Since new random samples are continualiy being drawn, the individuals in the same fractile in successive years cannot literally be the same individuals. The real issue is whether the individuals in a particular fractile in 1988 (e.g., the top 2 percent of taxpayers ranked by adjusted gross incomes) had

\footnotetext{
'For example, after the Tax Reform Act of 1986 many high income individuals who had previously had Subchapter C corporations converted them to Subchapter $S$ corporations. Since the income of $C-$ corporations is excluded from personal tax returns while the income from $S$-corporations is included, the result could be a substantial rise in reported individual income with no change in actual income.
} 
the same mean taxable income or labor supply in 1985 as the individuals in that same fractile had had in the earlier year. If they did not, the application of the "differences of differences" calculations to the corresponding fractiles in successive independent cross-sections would create misleading results.

Although the panel data of individual tax returns avoids these problems by permitting the tax returns of the same individuals to be followed over several years, there are also some disadvantages of the panel data. Because the panel sample is an unstratified random sample, the number of high income taxpayers is relatively small. There is also some attrition in the sample over time as some lower income individuals become nontaxable and as some single individuals who marry cease to be the primary taxpayer on the return. Although this unusual type of panel data attrition is nonrandom, it is likely to have relatively little effect on the middle and upper income married taxpayers who are the focus of this study.

The income of a taxpaying unit can be substantially affected by changes in marital status through marriage, divorce or the death of a member of the couple. The analysis presented in this paper therefore focuses on the largest marital status subgroup, those taxpayers who were married and filed a joint return in both 1985 and 1988.

'A similar analysis was carried out for taxpayers who were single in both 1985 and 1980 . The results (which are not presented in the paper) are broadly similar to the results presented for the "always married" taxpayers but are more difficult to interpret because a significant fraction of individuals who were single in 
Retirement also generally causes a substantial change in income. But since retirement itself is endogenous and is possibly affected by changes in taxes, it would be wrong to exclude from the sample individuals who retired between 1985 and 1988 . A separate analysis that excludes returns with taxpayers who were over age 65 in 1988 was also done and is summarized in section 4 below. Eliminating the older taxpayers reduces income variation that is related to age and causes the results about the effects of the 1986 tax rate changes to be clearer and stronger.

Despite the unstratified character of the sample and the focus on taxpayers who were married in 1985 and 1988 , the final sample (even after other deletions described below) has 3954 "medium income taxpayers" (with 1985 marginal tax rates between 22 percent and 38 percent), 236 high income taxpayers (with 1985 marginal tax rates of 42 to 45 percent) and 82 highest income taxpayers (with 1985 marginal tax rates of 49 or 50 percent).

\section{The Tax Reform Act of 1986}

The Tax Reform Act of 1986 combined sharp reductions in high marginal tax rates with base-broadening changes in tax rules. The combination was designed to be approximately revenue neutral and distributionally neutral on the assumption that there would be no behavioral response to the cax changes." To increase the political

1985 were no longer single in 1988 .

'See Fullerton (1993) for a very good analytic discussion of the Tax Reform Act of 1986. See also the discussion in Feldstein (1993). 
appeal of the tax proposal, the tax changes were actually structured so that tax revenue would decline in each broad income class (assuming no behavioral response) and so that the resulting revenue shortfall would be made up by an increase in the corporate income tax. ${ }^{10}$ An increase in the "standard deduction" and in the personal exemption caused a substantial number of low income taxpayers to have no taxable income.

The changes in the tax rules that accompanied the tax rate reductions mean that precautions must be taken in comparing incomes in 1985 and 1988. Four such changes are noteworthy.

First, adjusted gross income in 1985 excluded 60 percent of realized capital gains. That exclusion was eliminated by the Tax Reform Act of 1986. The current paper presents comparisons among different tax brackets both of "Full AGI" that includes all capital gaing in both years and of "AGI Excluding Capital Gains" that focuses on the portion of income that experienced the marginal tax rate reduction. Both measures indicate a substantial response of income to the reduction in marginal tax rates. Subsequent comparisons of taxable income are based on income excluding all

\footnotetext{
${ }^{10}$ The corporate tax was increased by eliminating the investment tax credit and lengthening depreciation lives. This had a positive temporary effect on the value of existing capital investments in equipment and business structures while reducing the net-of-tax return on invegtments in depreciable business capital in the future. Since the ownership of corporate stock and of business capital more generally is primarily by high income individuals, the form of increase of the 1986 corporate tax increase may have had adverse wealth and substitution effects on the labor supply of higher income individuals. To the extent that this is true, the elasticities of taxpayer behavior with respect to tax changes that are reported in section 6 of this paper will understate the effect of individual marginal tax rates.
} 


\begin{abstract}
capital gains.
Second, before 1986 some individuals used subchapter $C$ corporations which permitted them to pay lower rates of tax than the individual income tax, especially on profits below $\$ 100,000$. The desirability of such corporations was substantially reduced (primarily by the legislative repeal of the so-called General Utilities rule) in the Tax Reform Act of 1986. The standard practice after 1986 was for individuals who had used subchapter $C$ corporations to convert them to subchapter $S$ corporations, causing the previously excluded corporate income to be appear on their personal tax returns (in the same way that partnership income is treated.) A failure to take this into account in an analysis of the tax change could lead to an overestimate of the rise in income between 1985 and 1988. Since there is no way to obtain 1985 Subchapter $C$ incomes, the present analysis eliminates all taxpayers who adopted a Subchapter $S$ corporation between 1985 and 1988 .

Third, the 1986 tax reforms provided that certain "passive losses" (e.g.. losses in excess of $\$ 25,000$ on real estate partnership investments) could no longer be used to offset (i.e., "shelter") other income. Although there was a sharp decline in such investments after 1986, much or all of this decline would have occurred because of the fall in marginal tax rates even if passive losses had not been disallowed. The basic economics of such tax shelter investments made sense when taxpayers faced 50 percent marginal tax rates but not at the substantially lower marginal rates that prevailed after 1986 .
\end{abstract}


The analysis that follows presents two alternative ways of dealing with this change in passive losses. The first assumes that the reduction in tax logses is the result of the lower marginal tax rates while the other goes to the extreme of assuming that none of the reduced use of passive losses was due to lower tax rates but must be attributed to the new rules disallowing the use of such losses. The first therefore makes no special adjustment for losses; the second redefines taxable income by adding all losses to taxable income in both 1985 and 1988, implicitly assuming that the reduction in losses between 1985 and 1988 was the result of changes in tax rules and not a response to the lower marginal tax rates."

Fourth, the link between AGI and taxable income was also modified in two ways that must be taken into account to make the taxable income values for 1985 and 1988 comparable. First, the personal exemptions and the effective zero bracket amount for nonitemizers were both increased between 1985 and 1988, implying that with no change in behavior the taxable income corresponding to any given AGI would be lower in 1988 than in 1985. Second, in 1988 (but not in 1985) taxable income is defined to be net of the zero bracket amount and the personal exemptions so that the first dollar of taxable income is subject to tax. The 1985 taxable incomes are

\footnotetext{
${ }^{11}$ The tax return data separate partnerships with gross losses from partnerships with gross gains. The analysis in this paper adds gross (rather than net) losses to taxable income in both years. This extreme correction implicitly assumes not only that the reduction in losses was the result of the change in rules (rather than the reduction in rates) but also that all such losses were the result of tax avoidance planning and not just economic losses on ordinary business investments.
} 
all adjusted in the analysis that follows so that the comparisons of taxable incomes are all based on the 1988 definitions.

One final adjustment is necessary to make the modified taxable income for 1985 comparable to the taxable income that the taxpayer would report in 1988 if the taxpayer did not change his behavior. The 1985 taxable incomes are increased by the amount that the taxpayer's AGI exclusive of capital gains would have increased if it rose at the same rate as nominal personal income per capita (17.4 percent). This adjugted 1985 taxable income will be referred to as 1985 Adjugted Taxable Income.

With these adjustments, the differences among taxpayer groups in the change in taxable income between 1985 and 1988 should reflect changes in marginal tax rates, changes in individuals" market opportunities, and other nontax sources of change in taxpayer behavior, but not the changes in tax rules as such, ${ }^{12}$ Moreover, the observed behavior should reflect the way that tax

\footnotetext{
${ }^{12}$ There are of course some additional small changes in tax rules that have not been taken into account. Two deserve special mention. First, the rules for Individual Retirement Accounts were changed so that taxpayers with AGI over $\$ 40,000$ were no longer eligible for tax deductible IRAs if they participated in an employer-sponsored pension plan. The inability to take this deduction would raise taxable incomes but the increase would be proportionately greater for the lowest income group of taxpayers in this study (those classified as moderate income taxpayers) and would have a very small relative impact on the taxable incomes of the higher income groups of taxpayers. The result is to bias down. the estimated responsiveness of taxable income to changes in tax rates. The second change that is not reflected in this study is the increase in the Social security tax rates and tax base. The combined employer-employee OASDHI rate rose from 14.1 percent in 1985 to 15.0 percent in 1988. The maximum taxable base rose from $\$ 39,600$ to $\$ 45,000$, slightly less than the rise in average personal income. The increases are small and the impact is offset to some extent by the link between future benefits and current taxes.
} 
rate changes alter behavior under the post-1986 tax rules with limited opportunities for tax sheltering.

\section{Analysis and Results}

The analysis presented in this section relates changes in taxable incomes between 1985 and 1988 to the changes in the net-of tax rate (i.e., the net-of-tax income per dollar of additional pretax income) between those two years. The initial panel of taxpayers was reduced by restricting observations to taxpayers who were married in both 1985 and 1988 and by eliminating taxpayers who created an $S$-corporation between 1985 and 1988. The remaining observations were grouped by their marginal tax rate in 1985.

Table 1 shows the average AGI (column 2) and the number of observations in the sample (column 3) for taxpayers in each 1985 marginal tax rate class shown in column 1. For example, the 896 taxpayers in the sample whose 1985 marginal tax rate was 22 percent had an average adjusted gross income of $\$ 30,455$ in that year.

The average 1988 marginal income tax rate for this group of taxpayers was 15.0 percent, a 32 percent decline from the 22 percent marginal rate in 1985. To study taxpayer behavior it is preferable to describe the corresponding change in the net-of-tax rate, i.e., in the share of pretax income that the individual would retain after tax. This net-of-tax rate increased from $1.0-0.22=$ 0.78 to $1.0-0.15=0.85$, an increase of only 9 percent. ${ }^{13}$

${ }^{13}$.This ignores the role of the Social Security payroll tax. The combined employer-employee tax rate increased from 14.1 percent in 1985 to 15.0 percent in 1988 . 
Table 1

The Response of Taxable Income of Married Taxpayera to Changes in Marginal Tax Retes between 1985 and 1988

$\begin{array}{lll}1985 & \text { AGI } & \text { N } \\ \text { MTR } & 1985\end{array}$

$(\$ 000)$

(1)

(2)

(3)

(4)

Net of

Tax Rate
Percentage Changes of

\section{Adj .}

Eull AGI ex. AGI Capital
ATI plus Gross Loss

\begin{tabular}{|c|c|c|c|c|c|c|c|}
\hline 22 & 30.5 & 896 & 9.0 & 6.8 & 6.3 & 9.8 & 9.2 \\
\hline 25 & 36.1 & 1012 & 13.3 & 2.4 & 0.6 & 0.6 & 0.8 \\
\hline 28 & 42.6 & 786 & 15.5 & 0.9 & 1.9 & 2.2 & 1.3 \\
\hline 33 & 51.3 & 864 & 8.5 & 1.5 & -0.7 & -1.0 & -1.0 \\
\hline 38 & 66.9 & 396 & 16.1 & 5.1 & 6.1 & 6.4 & 5.1 \\
\hline 42 & 92.3 & 186 & 24.1 & 10.4 & 10.5 & 15.7 & 16.2 \\
\hline 45 & 126.1 & 50 & 30.9 & 14.8 & 10.6 & 13.3 & 10.6 \\
\hline 49 & 176.3 & 45 & 41.2 & 20.9 & 23.5 & 34.4 & 27.4 \\
\hline $\begin{array}{l}50 \\
50 a\end{array}$ & $\begin{array}{l}596.0 \\
511.3\end{array}$ & $\begin{array}{l}37 \\
35\end{array}$ & $\begin{array}{l}44.0 \\
44.0\end{array}$ & $\begin{array}{l}28.2 \\
46.4\end{array}$ & $\begin{array}{l}24.5 \\
49.5\end{array}$ & $\begin{array}{l}14.8 \\
42.0\end{array}$ & $\begin{array}{r}3.7 \\
23.9\end{array}$ \\
\hline $22 \ldots$ & -- & 3954 & 12.0 & 3.0 & 2.4 & 2.8 & 3.0 \\
\hline $42 \ldots$ & -- & 236 & 25.5 & 11.6 & 10.5 & 15.0 & 14.7 \\
\hline $\begin{array}{l}49 \ldots \\
49 \ldots\end{array}$ & 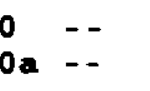 & $\begin{array}{l}82 \\
80\end{array}$ & $\begin{array}{l}42.4 \\
42.4\end{array}$ & $\begin{array}{l}26.4 \\
40.8\end{array}$ & $\begin{array}{l}24.2 \\
36.2\end{array}$ & $\begin{array}{l}20.2 \\
39.5\end{array}$ & $\begin{array}{r}9.6 \\
24.3\end{array}$ \\
\hline
\end{tabular}

All observations are for married taxpayers who Eiled joint tax returns for 1985 and 1988. Taxpayers who created a subchapter $S$ corporation between 1985 and 1988 are eliminated from the sample. The marginal tax rate group corresponding to 50 a excludes two taxpayers who were retired in 1988 . (092093) 
The percentage change in the net-of-tax rate is shown in column 4 of table 1 for each initial marginal tax rate level. The increase in the net-of-tax rate varies between 8.5 percent and 16 percent for individuals with 1985 marginal tax rates between 22 percent and 38 percent and then climbs rapidly, reaching a 44 percent increase in the net-of-tax rate for taxpayers with a 50 percent marginal tax rate in 1985.

The analysis excludes taxpayers with 1985 marginal tax rates below 22 percent for two reasons. First, many low income taxpayers became nontaxable as a regult of the 1986 tax reforms and therefore were no longer in the sample. Second, many of the low income taxpayers who did not become nontaxable were individuals whose incomes were temporarily depressed in 1985 and recovered to a more normal level in 1988. The income gains of those lower income individuals who remained in the sample would therefore reflect this selection and mean reversion bias. ${ }^{4}$

Because the sample sizes are relatively small for the top tax rate groups, calculations are presented in the lower part of the table that combine several individual 1985 marginal tax rate groups with the appropriate sample weights. Separate averages are presented for the "medium income group" with tax rates of 22

14 There may still be some mean reveraion tendency for both the low and high marginal tax rate groups. If the low tax rate individuals in the final sample had temporarily depressed income in 1985 or if the high tax rate individuals had temporarily increased income in 1985, the comparison of 1985 and 1988 incomes would understate the responsiveness to the tax rate changes. 
percent to 38 percent (identified in column 1 as $22 \ldots 38$ ), the high income group with tax rates of 42 and 45 percent, and the highest income group with tax rates of 49 and 50 percent. ${ }^{15}$

columns 5 compares the "full" adjusted gross incomes of taxpayers in 1985 and 1988, defined to include the full amount of capital gains in each year. More specifically, the numbers in column 5 are calculated by comparing the 1988 full AGI to the sum of the 1985 full AGI and the amount by which the 1985 AGI excluding capital gains would have increased if it had risen by the same 17.4 percent that per capita personal income rose during those years. ${ }^{26}$ For example, the actual Full AGI of taxpayers with 1985 MTRs of 22 percent rose 25 percent between 1985 and 1988 . Adjusting for the 17.4 percent rise in non-gain AGI implied by the rise in personal income implies a 6.8 percent net rise in Adjusted Full AGI .

The net rise in Adjusted Full AGI of the lowest five marginal rate groups varied between 0.9 percent and 6.8 percent with a weighted average (shown at the bottom of the table) of 3.0 percent. The relative net rise in Adjusted Full AGI then increases sharply and monotonically to reach 28 percent among taxpayers with 1985 marginal tax rates of 50 percent. Thus while lower income taxpayers, whose net-of-tax rates rose relatively little, saw

\footnotetext{
${ }^{25}$ The significance of the soa marginal tax rate group is discussed below.

16 If FAGI85 denotes the full AGI for 1985 (including all capital gains) and AGIXCG85 denotes the AGI for 1985 excluding all capital gains, the figures in column 5 show 100 [FAGI88/(FAGI85 + 0.174 AGIXCG85) - 1].
} 
their. Adjusted Full AGI levels rise by only a little more than real income per capita in the economy as a whole, the higher income taxpayers whose net-of-tax rates rose substantially saw their Adjusted Full AGI rise by 10 to 28 percentage points faster than per capita personal income.

Because the Tax Reform Act of 1986 did not reduce marginal tax rates on capital gains in the same way that it did for other income, to study the effect of lowering marginal tax rates it is appropriate to focus on income excluding capital gains. ${ }^{17}$ colum 6 shows the net rise in Adjusted AGI excluding capital gains between 1985 and 1988.10 Because capital gains are not large relative to the rest of AGI for taxpayers with incomes below the very highest tax groups, the figures in column 6 are almost identical to the net changes in Adjusted Full AGI (column 5) except for the very highest marginal tax rate groups. The overall pattern of the net changes in Adjusted AGI excluding capital gains is very similar to the net changes in the Adjusted Full AGI including all capital gains. There are very small increases in AGI in the groups for which the tax rate changes are small followed by much larger changes that increase monotonically with the relative size of the tax rate change.

The revenue consequence of reducing marginal tax rates depends

17 Although in the long run individuals might be able to substitute compensation in the form of capital gains for some ordinary income, this is unlikely to be a significant factor just two years after the Tax Reform Act of 1986 was passed.

"In the notation of footnote 16, the figures in column 6 represent 100 [(AGIXCG88/1.174 AGIXCG85) - 1]. 
on what happens to Taxable Income rather than to Adjusted Gross Income. Column 7 shows the percentage increases in Adjusted Taxable Income (excluding capital gains) between 1985 and 1988 . Recall that Adjusted Taxable Income for 1985 is obtained from actual 1985 taxable income by subtracting taxable capital gains, adding an amount equal to 17.4 percent of 1985 AGI excluding capital gains (the percentage increase in per capita personal income between those years), and then using the 1988 levels of the personal exemption and the standard deduction for nonitemizers. Adjusted taxable income for 1988 equals actual 1988 taxable income minus capital gains.

Although the percentage increases in adjusted taxable income vary somewhat erratically among the individual 1985 MTR groups, the overall general pattern is quite clear. The average increases in adjusted taxable income rose from 3 percent (relative to the 17.4 percent baeline increase which is part of the definition of adiusted taxable income) for taxpayers with 1985 MTRs below 40 percent to 15 percent for taxpayers with 1985 MTRs of 42 to 45 percent and to 20 percent for taxpayers with 1985 MTRs of 49 percent and 50 percent.

The increase in adjusted taxable income for the 50 percent marginal tax rate group is surprisingly only 15 percent. This anomalous result can be explained by the behavior of two millionaires (among the five millionaires in the sample) who appear to have retired between 1985 and 1988. The first of these became 65 between 1986 and 1988 and experienced a decline in salary from $\$ 1.9$ 
million in 1985 to zero in 1988. The second, who was already 65 years old in 1985 and had no salary in either year, experienced a decline in partnership income from $\$ 1.5$ million in 1985 to $\$ 569,000$ in 1988 . The retirement of these individuals is clearly related to age and not to the tax changes since those tax changes encouraged more work in 1988 than in 1985. When these two individuals are omitted from the sample, the remaining group of 35 taxpayers with 50 percent marginal tax rates in 1985 experienced a 42 percent rise in adjusted taxable income; this is shown as marginal tax rate group 50a. When combined with the 45 taxpayers in the 49 percent marginal tax rate group, the combined percentage change in adjusted taxable income is 39.5 percent.

This sensitivity of the results to a small number of observations is a consequence of using a nonstratified sample of panel data that includes retired and potentially retired individuals. The use of panel data that include older individuals makes the results particularly sensitive to exogenously determined retirement behavior. Moreover, since the sample is not stratified, there are relatively few high income individuals; this leaves the results sensitive to random events within this small group.

Before examining results for a sample that excludes individuals who were 65 years old by 1988, it is useful to consider the final column of Table 1 in which gross partnership losses are added to adjusted taxable incomes. As noted in section 3 , this would be appropriate only if the entire decline of partnership losses between 1985 and 1988 had been due to the changes in rules 
governing the taxpayers' ability to offset other income with such partnership losses but is not appropriate if the reduction in the use of such partnership losses was in whole or in part a response to the lower post -1986 tax rates themselves.

Partnership losses are not at all significant for taxpayer groups with 1985 marginal tax rates below 45 percent. A comparison of columns 7 and 8 shows that the changes in adjusted taxable income (column 7 ) and in adjusted taxable income plus gross partnership losses (column B) are essentially the same for taxpayers with 1985 marginal tax rates below 45 percent. Since partnership losses generally declined between 1985 and 1988, the addition of these losses for both years reduces the percentage increase in income between 1985 and 1988 for the taxpayers with marginal tax rates of 45 percent and higher. But even with this reduction, the income increases are substantially higher for the taxpayers in the groups with 1985 marginal tax rates of 42 percent through 49 percent than they are in the lower marginal tax rate groups.

The only departure from this pattern is with the highest income individuals who are in the 50 percent marginal tax rate group. For these 37 individuals, the combination of adjusted gross income and partnership losses is not significantly higher in 1988 than it had been in 1985; the difference is only 4 percent. This anomalous result is, however, due to the same two retirees whose behavior distorted the estimated change in adjusted taxable incomes. When these two individuals are omitted from the sample, 
the combination of adjusted taxable incomes and gross partnership losses in the 50 percent marginal tax rate group rises by 24 percent between 1985 and 1988, almost exactly the same as the increase in the 49 percent group; this is shown as marginal tax rate group 50a. When combined with the 45 taxpayers in the 49 percent marginal tax rate group, the combined percentage change in adjusted taxable income is 24.3 percent.

The anomalous behavior of the high income retirees suggest that a more meaningful analysis of the effect of tax rates on taxpayer behavior would be obtained by focusing on taxpayers who are below the age of 65 . Extending the analysis to older taxpayers in the context of a panel of data requires an explicit model of retirement (that separates age-related retirement behavior from other influences, including changes in tax rates) and of postretirement asset decumulation through spending or gifts.

Table 2 presents calculations similar to those presented in table 1 for a sample restricted to taxpayers who do not take an age exemption in 1988, indicating that neither spouse has reached age 65 by 1988 . This has the effect of reducing the sample by about 10 percent in all marginal tax rate groups below the 45 percent group and by about 30 percent in the top two groups.

The pattern of changes in adjusted gross incomes (columns 5 and 6) are similar in the two tables. The only significant difference is that the rise in AGI excluding capital gains is substantially greater among the non-aged in the 50 percent marginal tax rate group than in the broader sample. 


\section{Table 2}

The Response of Taxable Income of Non-Aged Marrled Taxpayers to Changer in Marginal Tax Rates between 1985 and 1988

\begin{tabular}{|c|c|c|c|c|c|c|c|}
\hline \multirow{2}{*}{$\begin{array}{l}1985 \\
\text { MTR }\end{array}$} & AGI & \multirow[t]{2}{*}{$\mathbf{N}$} & \multicolumn{3}{|c|}{ Percentage } & Changes of & \multirow[b]{2}{*}{$\begin{array}{l}\text { ATIplu } \\
\text { Gross } \\
\text { Loss }\end{array}$} \\
\hline & $(\$ 000)$ & & $\begin{array}{l}\text { Net of } \\
\text { Tax Rate }\end{array}$ & $\begin{array}{l}\text { Adj } \\
\text { FuI } 1 \\
\text { AGI }\end{array}$ & $\begin{array}{l}\text { Adjusted } \\
\text { AGI ex. } \\
\text { Capital } \\
\text { Gains }\end{array}$ & $\begin{array}{l}\text { Adjusted } \\
\text { Taxable } \\
\text { Income }\end{array}$ & \\
\hline (1) & (2) & (3) & (4) & (5) & (6) & (7) & (8) \\
\hline 22 & 30.7 & 800 & 9.0 & 9.4 & 8.4 & 13.6 & 13.4 \\
\hline 25 & 36.1 & 909 & 13.3 & 4.5 & 2.4 & 3.5 & 3.7 \\
\hline 28 & 42.7 & 713 & 16.3 & 3.9 & 4.7 & 6.0 & 5.0 \\
\hline 33 & 51.5 & 771 & 8.7 & 2.2 & 2.2 & 2.5 & 2.5 \\
\hline 38 & 67.5 & 345 & 16.1 & 8.0 & 8.1 & 9.6 & 8.8 \\
\hline 42 & 94.3 & 152 & 24.1 & 18.8 & 14.7 & 22.0 & 22.3 \\
\hline 45 & 126.9 & 45 & 30.9 & 12.4 & 14.8 & 18.5 & 15.3 \\
\hline 49 & 177.7 & 35 & 41.2 & 27.1 & 29.6 & 42.7 & 33.9 \\
\hline 50 & 479.0 & 22 & 44.0 & 18.4 & 70.6 & 92.4 & 51.1 \\
\hline
\end{tabular}

$\begin{array}{rrrrrrrr}22 \ldots 38 & -- & 3538 & 12.2 & 5.1 & 4.6 & 6.2 & 6.4 \\ 42.45 & -- & 197 & 25.6 & 17.0 & 14.7 & 21.0 & 20.3 \\ 49.550 & -- & 57 & 42.2 & 21.3 & 53.7 & 71.6 & 44.8\end{array}$

All observations are for married taxpayers under age 65 who filed joint tax returns for 1985 and 1988 with no age exemption in 1988 . Taxpayers who created a Subchapter $S$ corporation between 1985 and 1988 are eliminated from the sample.

$(092093)$ 
The evidence for adjusted taxable income shows a more consistent and stronger pattern of response to changes in marginal tax rates for the nonaged taxpayers than for the broader sample analyzed in Table 1 . This is just what would be expected since many of those over 65 are retired and can no longer adjust that part of their income. The taxpayers with a 50 percent marginal tax rate in 1985 experienced the largest increase in adjusted taxable income. This remains true even when gross partnership losses are added back to taxable income. The summary section of the table shows that the increase in adjusted taxable income rose from 6.2 percent among the middle income taxpayers to 21 percent among high income taxpayers and 72 percent among the highest income taxpayers. When gross partnership losses are added to adjusted taxable incomes, the increases are 6.4 percent, 20.3 percent and 44.8 percent.

\section{Elasticities of Taxable Income with Respect to Net-of-Tax Rates}

The evidence presented in section 4 implies substantial elasticities of taxable income with respect to the net-of-tax rates. Table 3 presents estimates of these elasticities using a differences-of-differences method, i.e., by comparing the differences in the percentage change in taxable income between pairs of marginal tax rate groups to the differences in the percentage change in the net-of-tax rates between the same groups. The analysis is based on the sample of non-aged married taxpayers whose behavior is described in Table 2 . 
Table 3

\section{Estimated Elasticities of Taxable Income with reapect to Net-of-Tax Ratea}

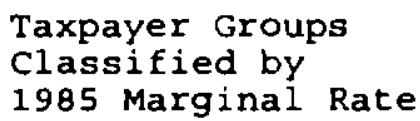

Medium $(22 \ldots 38)$
High $(42 \ldots 45)$
Highest $(49 \ldots 50)$
High minus Medium
Highest minus High
Highest minus Medium

\author{
Net of \\ Tax Rate
}

(1)

\author{
Adjusted \\ Taxable \\ Income
}

(2)
ATI plus by Gross Loss
Row

\section{- - - Percentage}

12.2

6.2

6.4

25.6

21.0

20.3

42.2

71.6

44.8

---- Differences of Differences --.-

$$
13.4
$$

14.8

13.9

16.6

50.6

$24 \cdot 5$

30.0

65.4

38.4

High minus Medium

Highest minus High

Highest minus Medium

High minus Medium
Highest minus High
Highest minus Medium

-- Implied Elasticity Estimates ---

The calculations in this table are based on observations for married taxpayers under age 65 who filed joint tax returns for 1985 and 1988 with no age exemption in 1988. Taxpayers who created a Subchapter $S$ corporation between 1985 and 1988 are eliminated from the sample.

(090493) 
This method implicitly assumes that there is a relation between the percentage change in taxable income between 1985 and 1988 and the percentage change in the net-of-tax rate with a common "constant term" that does not differ between marginal tax rate groups. The differencing eliminates the common constant term and provides an estimate of the slope term. Since both changes are measured as percentages, this slope coefficient is an estimated elasticity. ${ }^{29}$

Consider for example the comparison of the middle and high marginal tax rate groups. The net-of-tax rate increased by 12.2 percent for the first group and by 25.6 percent for the second group (shown in rows 1 and 2 of column 1 of Table 3), a difference of 13.4 percentage points (shown in row 4 of column 1). The corresponding increases in the adjusted taxable incomes for the two groups were 6.2 percent and 21.0 percent, a difference of 14.8 percentage points; these are shown in column 2. Comparing this difference in the adjusted taxable income increase to the difference in the net-of-tax rate increase implies an elasticity of 1.10 ; this is shown in row 7 of table 3 .

Similar calculations based on the comparison of the high marginal tax rate group (with 1985 MTRs of 42 to 45 percent) with the highest marginal tax rate group (with 1985 MTRs of 49 and 50

19 John Navratil has repeated this analysis for the years 1983 and 1985 when there were no changes in tax rates or tax rules to see if there is any systematic cendency for higher marginal tax rate individuals to experience relatively greater income increases. He found no evidence of faster income growth among higher marginal tax rate groups, confirming that the patterns reported in tables 1 and 2 are due to the 1986 tax reforms. 
percent) indicates a much higher elasticity of 3.05. An overall elasticity based on comparing the middle marginal tax rate group and the highest group is 2.14 .

Adding the gross partnership losses to adjusted taxable income lowers these estimated elasticities to $1.04,1.48$ and 1.25. Since some and perhaps all of the reduced use of partnership tax losses to offset other income reflects the reduction in marginal tax rates rather than the special rules disallowing partnership losses, the true elasticities probably lie between the limits shown in columns 2 and 3.

These elasticity values are quite similar to the estimates obtained by Lindsey (1987b), the only other published estimates of the elasticity of taxable income with respect to the net-of-tax rate. The similarity is striking since Lindsey's estimates are based on a different historic episode (the 1982-84 tax cuts) and a different method of estimation (non-panel tax return data.) Lindsey reported a variety of different elasticity estimates but concluded that "under the constant elasticity specification the elasticity of taxable income to after-tax share ranges from 1.05 to 2.75 with most of the data suggesting an elasticity between 1.6 and 1.8." (Lindsey, 1987b, page 197). When Lindsey allowed his elasticity estimate to vary with income, he also found that higher income taxpayers appear to have higher elasticities. The generally higher elasticity values in the Lindsey analysis may reflect the fact that in 1982 there were many opportunities to shelter income through tax losses and part of the observed response was a reduced use of those 
shelters.

\section{The Responsiveness of Wage and Salary Income to Tax Changes}

The panel data can in principle be used to study the responsiveness of wage and salary income to changes in marginal tax rates. Before looking at this analysis, it is important to emphasize that changes in wage and salary income do not measure changes in labor supply. Thig is true for two reasons.

First, there are types of labor supply that are not compensated by wage and salary income. These include primarily self-employment income and partnership income but can also include compensation in the form of capital gains on taxpayer-owned businesses. Second, not all employment compensation is in the form of wage and salary income. Variations in marginal tax rates can induce employees and employers to shift the form of employment compensation from taxable wage and salary payments to other forms of compensation that are either nontaxed or that appear as deferred income or capital gains. Both of these factors are likely to be particularly important at higher income levels where selfemployment is more common and greater discretion exists about the form of compensation.

A further caveat deserves mention. It is widely recognized that the distribution of wage income became less concentrated during the 1980s. Some of this may be because of technological and trade factors that had nothing to do with tax incentives. These changes make the interpretation of the observed pattern of wage and salary changes more difficult to interpret. It should be noted that 
most of the technological and trade reasons for changes in the distribution of wage income apply to incomes that are generally lower than those that are the primary focus of the current analysis.

Table 4 shows the percentage change in real wage and salary incomes and in the net-of-tax rate corresponding to each level of the 1985 marginal tax rate. ${ }^{20}$ Real wage and salary incomes rose by an average of 2.0 percent among taxpayers who in 1985 had marginal tax rates of 22 to 38 percent. These represent taxpayers with 1985 mean AGIs between $\$ 31,000$ and $\$ 68,000$. The rate of increase of wage and salary income rose much more rapidly at 10.8 percent among high tax rate individuals (with 1985 MTRs of 42 and 45 percent). Taken together, the difference between the change in real wage and salary increase and the change in the net of tax rate implies an elasticity of 0.66 of real wages and salaries with respect to the net-of-tax rate.

The rate of wage increase in the very highest marginal tax rate group is dominated by the experience of the two millionaires (individuals with 1985 AGI greater than $\$ 1$ million) in this sample of nonaged taxpayers. ${ }^{21}$ The first of these individuals experienced a nominal salary decline from $\$ 359,000$ in 1985 to $\$ 164,000$ in 1988 but nevertheless had an 8 percent rise in AGI excluding capital

\footnotetext{
${ }^{20}$ To calculate the change in real wage and salary incomes, 1985 wage and salary incomes were restated in 1988 dollars using the CPI-U increase of 9.94 percent.

21 Note that these two individuals are not the ones that confused the analsysis of the general nonaged population.
} 
Table 4

The Response of Wages and Salaries of Non-Aged Married Taxpayers to Changes in Marginal Tax Rates between 1985 and 1988

$\begin{array}{ll}1985 & \text { AGI } \\ \text { MTR } & 1985 \\ & (\$ 000)\end{array}$

(1)

(2)

$$
22
$$

25

30.7

36.1

42.7

51.5

67.5

94.3

152

$45 \quad 126.9$

45

35

$49 \quad 177.7$

50

479.0

22

20

$50 \times \quad 193.0$

$\begin{array}{ll}50 y & 1157.7\end{array}$

N

Net of Tax Rate

Net of Tax Rate

(4)

9.0

13.3

16.3

8.7

16.1

24.1

30.9

41.2

44.0

44.0

44.0
Changes of

Real Wage and Salary Income

(5)

6.4

1.5

1.7

0.3

1.3

8. 8

17.2

13.9

$-3.6$

11.3

$-20.0$

22. .38 -

3538

12.2

2.0

$42 \ldots 15 \ldots$

197

25.6

10.8

$49 . .50 \quad-$

57

42.2

2.9

19..50x -.

55

42.1

12.6

Wage and salary income for 1985 is adjusted to 1988 price levels by the CPI-U increase. All observations are for married taxpayers under age 65 who filed joint tax returns for 1985 and 1988 with no age exemption in 1988. Taxpayers who created a subchapter $S$ corporation between 1985 and 1988 are eliminated from the sample. The group classified as $50 x$ had a 50 percent marginal tax rate in 1985 but 1985 AGI below $\$ 1$ million while the taxpayers classified as $50 y$ had 1985 AGI over \$1 million. (090493) 
gains. The second individual experienced a nominal salary decline from $\$ 3.4$ million to $\$ 3.1$ million but nevertheless had a rise in AGI excluding capital gains of more than $\$ 1$ million. It is clear that ordinary models of labor supply are inappropriate for describing the behavior of these complex situations.

When the two millionaires are excluded from the data, the remaining individuals in the 50 percent marginal tax rate group (denoted by line $50 x$ of Table 4) had an 11.3 percent rise in real wage and salary income. Caution must obviously be taken in interpreting even this number since some of the other individuals with very high incomes may also have wage and salary income changes that are not representative of their changes in total labor compensation.

It seems safest to conclude that any useful analysis of wage and salary income as a measure of labor income must be restricted to individuals who are not at the highest income levels. A skeptic might be justified in concluding that no useful analysis of the labor income of very high income individuals is possible and that attention should focus on broader measures like taxable income or adjusted gross income.

\section{An Application to the 1993 Tax Rate Increases}

The estimated elasticity of taxable income that was discussed in section 5 can be used to approximate the potential revenue effect of the increase in personal tax rates that was enacted in 1993. The legislation raised the marginal rate of income tax only 
on incomes over $\$ 140,000^{22}$, increasing the rate from 31 percent to 36 percent between $\$ 140,000$ and $\$ 250,000$ and then to 39.6 percent on incomes over $\$ 250,000$. The legislation also removed the existing $\$ 135,000$ ceiling on the Medicare (HI) payroll tax base. Since the Medicare tax is a combined. 2.9 percent divided equally between employers and employees, the combined effect of the two changes is basically to raise the personal tax rate from 31 percent to 39 percent between $\$ 140,000$ and $\$ 250,000$ and to 42 percent above $\$ 250,000.23$

These tax rate changes reduced the net-of-tax income per dollar of gross income from 69 percent to 61 percent for taxpayers with incomes under $\$ 250,000$ and from 69 percent to 58 percent for taxpayers with incomes over $\$ 250,000$. These represent reductions of 11.5 percent and 15.9 percent respectively.

An analysis of two representative high income taxpayers shows that the estimated elasticities imply that the recent legislation is likely to produce little additional tax revenue.

Consider first a couple with taxable income of $\$ 180,000$, the level of income that the clinton Administration identified as the median taxpayer among those who would experience an increased tax rate (A Vision of Change for America, 1993). With no behavioral response to the higher marginal tax rates, the proposed tax changes

\footnotetext{
${ }^{22}$ This is true for married taxpayers filing jointly. The analysis in this section uses the specific provisions of the law for each taxpayer group.

${ }^{23}$ This discussion draws on Feldstein and Feenberg (1993).
} 
would raise $\$ 2,000$ of additional personal income tax (5 percent of the $\$ 40,000$ of income between $\$ 140,000$ and $\$ 180,000$ ) and $\$ 1,305$ of additional HI payroll tax $(2.9$ percent of the $\$ 45,000$ of income between $\$ 135,000$ and $\$ 180,000)^{24}$, for a total revenue gain by the Treasury of $\$ 3,305$.

The tax rate increases represent an 11.5 percent reduction in the net-of-tax rate. The elasticity estimates presented in section 5 range from a low of 1.04 to a high of 3.05 . Even the elasticity of 1.04 implies that the 11.5 percent decline in the net-of-tax share would induce a 12 percent decline in taxable income, from $\$ 180,000$ to $\$ 159,000$. Because of the structure of the proposed tax increase, this decline in taxable income would cause an actual decline in the amount of tax paid. This revenue loss occurs because the $\$ 21,000$ reduction in taxable income (from $\$ 180,000$ to $\$ 159,000$ ) reduces current revenue by $\$ 6,510$ (at the 31 percent existing marginal rate) while the 5 percent increase in the personal tax rate on the $\$ 19,000$ (between $\$ 140,000$ and $\$ 159,000$ ) raises only $\$ 950$ in revenue and the 2.9 percent $H I$ tax on the $\$ 24,000$ (between $\$ 135,000$ and $\$ 159,000)$ raises only $\$ 696$ for a total of $\$ 1646$. The difference between the $\$ 6510$ revenue loss and the $\$ 1646$ revenue gain implies a net loss to the Treasury of $\$ 4864$ for this

\footnotetext{
24 This assumes that there is a full $\$ 45,000$ of wage and salary income in excess of $\$ 135,000$ per individual. If the couple contained two wage earners and each had less than $\$ 135,000$ of income subject to the HI tax, the proposed extension of the HI tax base would not raised any additional revenue.
} 
representative high income taxpayer. ${ }^{25}$

The revenue effect of the new legislation improves as income rises. Consider therefore a couple with $\$ 500,000$ of taxable income. With no behavioral response, this couple would pay $\$ 37,585$ more in taxes under the current tax rates than under the pre-1993 tax rates. But with the lowest elasticity of 1.04 , the 16.5 percent decline in the net-of-tax share implies a 17 percent decline in taxable income, from $\$ 500,000$ to $\$ 415,000$. The net revenue gain to the Treasury would be only $\$ 1460$ or less than one-half of one percent of the initial taxable income.

Although no attempt will be made here to compare the deadweight loss of the higher tax rate with this relatively small revenue increase, it should be noted that raising the marginal tax rate from 31 percent to 42 percent would increase the deadweight loss of the tax by approximately 80 percent. ${ }^{26}$

The higher tax rates in the 1993 legislation produce little or no additional revenue because there is no increase in tax rates on the first $\$ 140,000$ of income. A relatively small reduction in total

2s The Treasury would still lose money even if the couple does not face any increase in HI tax. The rise in the personal tax rate from 31 percent to 36 percent reduces the net of tax rate by 7.2 percent. The elasticity of 1.04 implies that taxable income would decline by 7.5 percent, from $\$ 180,000$ to $\$ 166,541$. The $\$ 13,459$ decline in income that would have been taxed at 31 percent implies a loss of individual income tax revenue of $\$ 4172$. This far outweighs the additional 5 percent tax on the income between $\$ 140,000$ and $\$ 166,541$, a revenue gain of $\$ 1327$. The net effect of the two is a revenue decline of $\$ 2845$.

26 Since the deadweight loss is approximately proportional to the square of the marginal tax rate, raising the marginal tax rate from 31 percent 42 percent increases the deadweight loss by a factor of $(42 / 31)^{2}=1.84$. 
taxable income therefore represents a substantial proportional reduction in the part of the income that is to be taxed at a higher rate. Moreover the taxable income that has been eliminated would have been taxed at a rate that is high ( 31 percent) relative to the increases in the tax rate 17.9 percent below $\$ 250,000$ and 11 percent over $\$ 250,000.1$

It is the structure of the tax increase, rather than the final tax rate or the degree of taxpayer responsiveness, that causes the particularly large revenue losses for most taxpayers. To see this, note that increasing a proportional income tax from 31 percent to 39 percent would raise substantial revenue even if taxpayers responded with an elasticity of 1.04 with respect to the 11.5 percent decrease in the net-of-tax rate. More specifically, if a taxpayer with $\$ 180,000$ of taxable income now paid 31 percent on all of that income (a tax of $\$ 55,800)$, an increase in that tax rate to 39 percent would increase revenue by nearly 11 percent (to $\$ 61,776$ ) even if pretax income fell by 12 percent to $\$ 158,400$.

The aggregate revenue effect of the 1993 tax rate changes can be estimated with the help of the NBER's TAXSIM Model. ${ }^{27}$ The TAXSIM model uses a stratified random sample of almost 100,000 individual tax returns provided by the Internal Revenue Service. The most recent data are for 1989 and have been adjusted to estimated 1993

27 An earlier analysis of the proposed tax changes that were eventually enacted was reported in in Feldstein and Feenberg (1993). That analysis was done before the current elasticity estimates were available and assumed somewhat lower estimates than even the lowest value estimated in this sample. 
income levels. ${ }^{28}$

Three caveats should be noted about applying the estimated elasticity of individual taxable income to the 1993 tax reforms. First, the effect of eliminating the $\$ 135,000$ ceiling on the HI payroll tax base should probably be evaluated with a lower elasticity than the response to the 1986 personal rate changes since the HI tax applies only to labor income. Second, to the extent that individuals will reduce taxable income by shifting ordinary income to deferred compensation, capital gains, insurance, etc.. some future tax will be paid to the federal government. Finally, individuals who reduce their taxable income in ways that simultaneously increase the taxable income of their employers (e.g., by nonqualified retirement programs) may not alter the government's total tax collection.

With no behavioral response, the TAXSIM model implies that the cax rate changes enacted in 1993 would raise tax liabilities by $\$ 25.8$ billion at 1993 income levels. If however taxable income declines by 12 percent for individuals with incomes between $\$ 140,000$ and $\$ 250,000$ and by 16.5 percent for individuals with incomes over $\$ 250,000$ (i.e., by the amounts implied by the lowest estimated elasticity (1.04) of taxable income to net-of-tax rates), tax revenue would increase by only $\$ 3.4$ billion.

28 The TAXSIM model has been modified to analyze the extension of the 2.9 percent payroll tax to incomes above $\$ 135,000$. To calculate the increase in the HI tax base for each tax return, we use a statistical method to divide the 1989 wage and salary income (from line 1 of tax form 1040) between the two spouses in a way that reproduces the relation between spouses' incomes in the 1989 Current Population Survey. 


\section{Concluding Comments}

The evidence presented in this paper shows a substantial response of taxable income to changes in marginal tax rates. The elasticity estimates are obtained by using panel data that trace the tax returns of the same individuals before and after the 1986 Tax Reform Act. The differences-of-differences calculation based on tax returns for 1985 and 1988 grouped by 1985 marginal tax rates implies an elasticity of taxable income with respect to the marginal net-of-tax rate that is at least one and could be substantially higher.

If the long-run response to a change in marginal tax rates is greater than the short run response (e.g, because it involves changes in occupation, location, education, etc.), this analysis of only two years' experience after the 1986 tax rate changes may understate the long run sensitivity of taxable income to changes in tax rates.

The estimated response of taxable income is not the same as an estimate of the response of labor supply to changes in tax rates. Taxable income can be changed by varying not only labor supply but also the forms of compensation, the investment of assets, and the extent of spending on tax-deductible activities. Some evidence is presented in the current study on the sensitivity of wage and salary income to the net-of-tax rate which ouggests that it is substantially lower than the taxable income elasticities but still substantially higher that traditional labor supply elasticities. 
The estimated response of taxable income with respect to changes in tax rates has important implications for revenue estimating and for the design of tax and budget policy. For example, the lowest estimated elasticity implies that the tax rate changes enacted in 1993 will lead to little or no additional personal income tax revenue despite the very substantial increase in marginal tax rates. It follows that these tax rates could be reduced to their pre-1993 levels with little or no revenue loss. 


\section{References}

Auerbach, Alan "Capital Gains Taxation in the United States." Brookings Papers on Economic Activity, 1988

Congressional Budget office, How Capital Gains Tax Rates Affect Revenues: The Historical Evidence, Washington DC: Government Printing office, 1988

Eissa, Nada "Taxation and Labor Supply of Married Women: The Tax Reform Act of 1986 as a Natural Experiment," unpublished paper, 1993.

Feenberg, Daniel and James Poterba "Income Inequality and the Incomes of Very High Income Taxpayers," Tax Policy and the Economy. 1993

Feldstein, Martin "Personal Taxation and Portfolio Composition," Econometrica, 44 (1976) pp 631-50

Feldstein, Martin Capital Taxation, Cambridge: Harvard University Press, 1983

Feldstein, Martin "American Economic Policy in the 1980s: A Personal Statement," in M. Feldstein (ed.) American Economic Policy in the 1980s Chicago: University of Chicago Press, 1993

Feldstein, Martin and Charles clotfelter "Tax Incentives and Charitable Contributions in the United States," Journal of Public Economics, 1976

Feldstein, Martin and Daniel Feenberg "Higher Tax Rates with Little Revenue Gain: An Empirical Analysis of the Clinton Tax Plan," Tax Notes, March 22, 1993.

Fullerton, Donald "Inputs to Tax Policymaking: the Supply Side, the Deficit and the Level Playing Field" in M. Feldstein (ed.) American Economic Policy in the 1980s Chicago: University of Chicago Press, 1993

Gruber, Jonathan and James Poterba "Tax Incentives and the Decision to Purchase Health Insurance: Evidence from the Self Employed," NBER Working Paper No. 4435, 1993

Hausman, Jerry "Taxes and Labor Supply," in Alan Auerbach and Martin Feldstein (eds.), Handbook of Public Economics, vol. 1 Amsterdam: North Holland, 1991 pp. 213-264

Heckman, James "What Has Been Learned About Labor Supply in the 
Past Twenty Years?", American Economic Review, 1993, 83:2, pp 116-121.

Lindsey, Lawrence "Capital Gains: Rates, Realizations and Revenues," in M. Feldstein (ed.), The Effects of Taxation on Capital Accumulation. Chicago: University of Chicago Press. $1987 \mathrm{a}$

Lindsey, Lawrence "Individual Taxpayer Response to Tax Cuts: 19821984," Journal of Public Economics, 33 (1987b) pp 173-206

MaCurdy, Thomas, David Green and Harry Paarsch, "Assessing Empirical Approaches to Analyzing Taxes and Labor Supply," Journal of Human Resources, 1990, vol. 25, pp. 415-490

Mroz, Thomas "The Sensitivitry of an Empirical Model of Married Women's Hours of Work to Economic and statistical Assumptions," Econometrica, July 1987, 55, pp 768-800

Pencavel, John "Labor Supply of Men," in Orley Ashenfelter and Richard Layard (eds.), Handbook of Labor Economics, Amsterdam: North Holland, 1986, pp. 3-102

Poterba, James "Tax Policy Toward Housing: Preliminary Evidence on the Effects of Recent Tax Reforms," in J. Slemrod (ed.) Do Taxes Matcer Cambridge: MIT Press, 1990, pp 141-160

Rosen, Harvey "Taxes in a Model with Joint Wage-Hours Determination," Econometrica, 1976, vol 44

Rosen, Harvey "Housing Subsidies: Effects on Housing Decisions, Efficiency and Equity," in Alan Auerbach and Martin Feldstein (eds.), Handbook of Public Economics, vol. 1 Amsterdam: North Holland, 1991

Taylor, Amy and Gail Wilensky, "The Effect of Tax policies on Expenditures for Private Health Insurance," in Jack Meyer, ed., Market Reforms in Health Care: Current Issues, New Decisions, Strateqic Decisions. Washington DC: American Enterprise Ingtitute, 1983

Triest, Robert "The Effect of Income Taxation on Labor Supply in the United States," Journal of Human Resources, 25 (1990) pp $491-516$ 


\begin{tabular}{|c|c|}
\hline Number & Author \\
\hline 4459 & $\begin{array}{l}\text { Bemard Dumas } \\
\text { Bruno Solnik }\end{array}$ \\
\hline 460 & $\begin{array}{l}\text { Martin Gaynor } \\
\text { Gerard F. Anderson }\end{array}$ \\
\hline 4461 & $\begin{array}{l}\text { Kevin Lang } \\
\text { William T. Dickens }\end{array}$ \\
\hline 4462 & Michael D. Hurd \\
\hline 4463 & $\begin{array}{l}\text { Boyan Jovanovic } \\
\text { Glenn MacDonald }\end{array}$ \\
\hline+464 & $\begin{array}{l}\text { Richard B. Freeman } \\
\text { Robert Gibbons }\end{array}$ \\
\hline 4465 & Richard Baldwin \\
\hline 4466 & $\begin{array}{l}\text { Rebecca Henderson } \\
\text { lain Cockbum }\end{array}$ \\
\hline 4467 & Richard K. Lyons \\
\hline 4468 & $\begin{array}{l}\text { Kachanine G. Abraham } \\
\text { Susan K. Taylor }\end{array}$ \\
\hline$\$ 469$ & $\begin{array}{l}\text { Jonathan Gruber } \\
\text { Brigitte C. Madrian }\end{array}$ \\
\hline 4770 & $\begin{array}{l}\text { Christopher D. Carroll } \\
\text { David N. Weil }\end{array}$ \\
\hline 4471 & Richard K. Lyons \\
\hline$\$ 472$ & $\begin{array}{l}\text { Giuscppe Bertola } \\
\text { Ricardo J. Caballero }\end{array}$ \\
\hline 4473 & $\begin{array}{l}\text { Prajit K. Dutta } \\
\text { Saul Lach } \\
\text { Aldo Rustichini }\end{array}$ \\
\hline$\$ 474$ & $\begin{array}{l}\text { William Easterly } \\
\text { Michacl Kremcr } \\
\text { Lant Pritchett } \\
\text { Lawrence H. Summers }\end{array}$ \\
\hline
\end{tabular}

Title $\underline{\text { Datc }}$

The World Price of Foreign Exchange Risk $\quad 9 / 93$

Uncertain Demand, the Structure of Hospital Costs, and the Cost of Empty Hospital Beds

Bilateral Search as an Explanation for Labor Market Segmentation and Other Anomalies

The Effect of Labor Market Rigidities on the Labor Force Bchavior of Older Workers

Competitive Diffusion

$9 / 93$

Getling Together and Breaking Apart: The

$9 / 93$

Decline of Centralized Collective Bargaining

A Domino Theory of Regionalism $\quad 9 / 93$

Scale, Scope and Spillovers: The Determinants $9 / 93$ of Research Productivity in the Pharmaceutical Industry

Optimal Transparency in a Dealership Market with an Application to Foreign Exchange

Firms' Use of Outside Contractors: Theory and

$9 / 93$ Evidence

Health Insurance Availability and the Retirement

$9 / 93$

Decision

Saving and Growth: A Reinterpretation

Cross Sectional Efficiency and Labor Hoarding in a Matching Model of Unemployment

Better Late than Early: Vertical Differentiation in the Adoption of a New Technology 


\begin{tabular}{|c|c|}
\hline Number & Author \\
\hline 475 & Jean Olson Lanjouw \\
\hline 4476 & Brigitte C. Madrian \\
\hline+477 & David N. Weil \\
\hline$\$ 478$ & $\begin{array}{l}\text { Paul Krugman } \\
\text { Robert Lawrence }\end{array}$ \\
\hline 4479 & $\begin{array}{l}\text { Jonathan Gruber } \\
\text { Brigitte C. Madrian }\end{array}$ \\
\hline 480 & $\begin{array}{l}\text { George Baker } \\
\text { Roben Gibbons } \\
\text { Kevin J. Murphy }\end{array}$ \\
\hline$\$ 481$ & $\begin{array}{l}\text { Michael D. Bordo } \\
\text { Ehsan U. Choudhri } \\
\text { Anna J. Schwartz }\end{array}$ \\
\hline 4482 & Alwyn Young \\
\hline 483 & David Card \\
\hline$\$ 484$ & $\begin{array}{l}\text { Kiminor Massuyama } \\
\text { Takaaki Takahashi }\end{array}$ \\
\hline$\$ 485$ & $\begin{array}{l}\text { Christina D. Romer } \\
\text { David H. Romer }\end{array}$ \\
\hline 486 & $\begin{array}{l}\text { Alberto Alesina } \\
\text { Roberto Perolli }\end{array}$ \\
\hline 4487 & $\begin{array}{l}\text { Steven N. Durlauf } \\
\text { Louis J. Maccini }\end{array}$ \\
\hline 4488 & $\begin{array}{l}\text { Herschel 1. Grossman } \\
\text { Murat Iyigun }\end{array}$ \\
\hline+489 & $\begin{array}{l}\text { Severin Borenstein } \\
\text { Andrea Shepard }\end{array}$ \\
\hline 4490 & $\begin{array}{l}\text { V. V. Chari } \\
\text { Lawrence J. Christiano } \\
\text { Patrick J. Kehoe }\end{array}$ \\
\hline
\end{tabular}

Palent Protection: Of What Value and for How Long? 9/93

Employment-Based Health Insurance and Job Mobility: 9/93 Is There Evidence of Job-Lock?

Intergenerational Transfers, Aging, and Uncertainty $9 / 93$

Trade, Jobs, and Wages $\quad 9 / 93$

Limited Insurance Portability and Job Mobility: The $\quad 9 / 93$

Effects of Public Policy on Job-Lock

Subjeclive Performance Measures in Optimal Incentive Contracts

Could Stable Money Have Averted The Great Contraction?

Lessons from the East Asian NICs: A Contrarian $10 / 93$ View

Using Gcographic Variation in College Proximity to $10 / 93$ Estimate the Retum to Schooling

Self-Defeating Regional Concentration

Credit Channel or Credit Actions? An Interpretation of the Postwar Transmission Mechanism

Income Distribution, Political Instability, and $10 / 93$ Investment

Measuring Noise in Inventory Models

Population Increase, Extralegal Appropriation and the End of Colonialism

$10 / 93$

Dynamic Pricing in Retail Gasoline Markets

$10 / 93$

Optimal Fiscal Policy in a Business Cycle Model

$10 / 93$ 


\begin{tabular}{|c|c|c|c|}
\hline viumber & Author & Title & Dalc \\
\hline H9I & $\begin{array}{l}\text { Orley Ashenfeller } \\
\text { David J. Zimnerman }\end{array}$ & $\begin{array}{l}\text { Estimates of the Returns to Schooling from Sibling } \\
\text { Data: Fathers, Sons, and Brothers }\end{array}$ & $10 / 93$ \\
\hline+492 & $\begin{array}{l}\text { Steven J. Davis } \\
\text { John Haltiwanger } \\
\text { Scolt Schuh }\end{array}$ & $\begin{array}{l}\text { Small Busincss and Job Creation: Dissecting the } \\
\text { Myth and Reassessing the Facts }\end{array}$ & $10 / 93$ \\
\hline $4+93$ & $\begin{array}{l}\text { David K. Backus } \\
\text { Patrick J. Kchoc } \\
\text { Finn E. Kydland }\end{array}$ & Intemational Business Cycles: Theory and Evidence & $10 \% 3$ \\
\hline+494 & $\begin{array}{l}\text { Douglas Holu-Eakin } \\
\text { David Joullaian } \\
\text { Harvey S. Rosen }\end{array}$ & $\begin{array}{l}\text { Sucking It Out: Entreprencurial Survival and } \\
\text { Liquidity Constraints }\end{array}$ & $10 / 93$ \\
\hline 4.495 & $\begin{array}{l}\text { Andrew K. Rose } \\
\text { Lars E. O. Svensson }\end{array}$ & European Exchange Ratc Credibility Before the Fall & $10 / 93$ \\
\hline 496 & Martin Fcldsicin & $\begin{array}{l}\text { The Effect of Marginal Tax Rates on Taxable } \\
\text { Income: A Pancl Study of the } 1986 \text { Tax Reform Act }\end{array}$ & $10 / 93$ \\
\hline \multicolumn{4}{|c|}{$\begin{array}{l}\text { Copies of the above working papers can be obtaincd by sending } \$ 5.00 \text { per copy (plus } \$ 10.00 \text { per order } \\
\text { iage and handling for all locations outside the continental U.S.) to Working Papers, NBER, } 1050 \\
\text { husilts Avenuc. Cambridge. MA } 02138-5398 \text {. Advance payment is required on all orders. Payment may } \\
\text { c by check or credit card. Checks should be made payable to the NBER and must be in dollars drawn on } \\
\text { bank. If paying by credit card, include the cardholder's name, account number and expiration date. For } \\
\text { orders. please be sure to include your retum address and telephone number. Working papers may also } \\
\text { red by telephone (617-868-3900), or by fax (617-868-2742). }\end{array}$} \\
\hline
\end{tabular}




\section{National Bureau of Economic Research}

\section{Workding Paper Subscriptuon Order Form}

$\square$ Full subscriptions*

Partial subscriptions

$\square$ Corporate Finance

$\square$ Stocks, Bonds, and Foreign Currency

口 Intemational Finance and Macroeconomics

口 Iniemational Trade and Investment

口 Monetary Economics

$\square$ Economic Fluctuations

- Long-Run Economic Growth

Sources of Productivity Growth

$\square$ Taxation

$\square$ Labor Studies

$\square$ Economics of Health and Health Care

$\square$ Economics of the Elderly

$\square$ Incustrial Organization

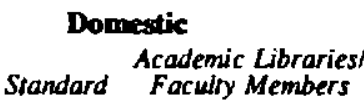

$\$ 1300$

\section{0}

300

270

270

$$
150
$$$$
270
$$$$
150
$$$$
70
$$$$
270
$$$$
270
$$$$
150
$$$$
\begin{array}{r}
150 \\
70
\end{array}
$$$$
\begin{aligned}
& 70 \\
& 70
\end{aligned}
$$

口 Technical Working Papers

- Historical Development of the American Economy 70

\section{Foreign** \\ Academic Librariest \\ Siandard Faculty Members}

$\$ 650 \quad \$ 1625 \quad \$ 975$

$\begin{array}{rrr}75 & 350 & 110 \\ 75 & 350 & 110 \\ 135 & 350 & 210 \\ 135 & 350 & 210 \\ 75 & 200 & 110 \\ 135 & 350 & 210 \\ 75 & 200 & 110 \\ 35 & 85 & 50 \\ 135 & 350 & 210 \\ 135 & 350 & 210 \\ 75 & 200 & 110 \\ 35 & 85 & 50 \\ 35 & 85 & 50 \\ 35 & 85 & 50 \\ 35 & 85 & 50\end{array}$

- A full subscription includes all topics listed under "pantial subscriptions" except for Technical Working Papers and papers on the Historical Development of the American Economy. These must be ordered in addition to the full subscription.

** Please inquire about subscription prices tor Aurica and Australia.

\section{PAYMENT OPTIONS}

$\square$ YES! Please begin my subscription to the NBER Working Paper Series. I have indicated above which papers I would like to receive.

By Phone: (617) $868-3900$

By FAX: (617) $868-2742$

Please mail my papers to this address:

By Mail: Publications Department

National Bureau of Economic Research 1050 Massachusetts Aye.

$\square$ Payment in the amount of enclosed.

$\square$ Please charge my: $\square$ VISA $\square$ MasterCard

Name

Address

Card Number:

Card expiration:

Phone:

Signature:

FAX: 